\title{
Synthesis and characterization of gold nanoparticles using fruit extract of Crescentia cujete $L$
}

\author{
Fauzan Amin ${ }^{1,}{ }^{*}$, Micha Mahardika $^{1}$ and Nada Morisca ${ }^{1}$ \\ 'Department of Chemistry, Sekolah Tinggi Analis Kimia Cilegon, Cilegon, Indonesia \\ ${ }^{*}$ Corresponding author: (FA), khotibkhottob@gmail.com
}

DOI: 10.24114/jpkim.v1li3.15737

Received: II October 2019; Accepted: 27 November 2019

\begin{abstract}
:
Nanoparticles play important role in biotechnology such as food and drug industries. Gold nanoporticles(Au-NPS) have been wdely used in any drug therapies like drug delivery system for cancer, tumor, and diabetes treatment. Recently, Au-NPS have been devoleped to increase drug selectivity between tumor and normal cells. In the present studies, we use the fresh fruit ekstract (FFE) of crescentia cujete $\mathrm{L}$ mediated blue green alga for the synthesis of Au-NPS. The characterization of Au-NPS was carried out by using UV-Vis spectroscopy, Fourier transform infrared spectroscopy (FTIR), and Transmission Electron spectroscopy (TEM). UV-VIS spectrometry indicated formation of nanoparticles which produces an intense absorbance peak at $531 \mathrm{~nm}$. FTIR reveales the functional group involved in reduction and stabilization of Au-NPS. TEM have shown the morphology of Au-NPS with mean size $10,11 \mathrm{~nm}$.
\end{abstract}

Keywords: Crescentia cujete; gold nanoparticles; green alga

\section{Introduction}

Nanotechnology, a combination of principles involving biology, physical and chemical. Nanoparticles have a special place in nonotechnologi due to which they have been widely used in daily lives like detecting environmental toxic metals, diagnostic imaging, biosensing, cancer therapeuticsand targeted drug delivery.

Generally the synthesis of Au-NPs has been carried out using microwave irradiation, electrochemical, thermal decomposition and chemical reduction. Rohiman et al. (2014) used sodium citrate as a reducing agent which may hamper the surface modifications and functionalization of agents for particular applications, require high energy, usage of toxic chemicals and leaves hazardous by-products. Inayah et al. (2014) used mangosteen extract act as bioreductor and Polyvinyl alcohol (PVA) as stabilizer to control the growth of Au-NPS. PVA is synthetic polymer can be potentially harmful and Non-biodegradable materials. Blue green alga Spirulina platensis also has been used in synthesis of AuNPs with smaller size (average $5 \mathrm{~nm}$ ) and uniform shape (Suganya et al. 2015). AuNPs can be used as nanocarrier in the treatment of brain tumor which have ability to deliver the drug at targeted site (Tripathi et al. 2015).

Plant based synthesis is more advantages due to their its therapeutic potency as bactericidal, fungicidal, nematicidal, mosquitocidal and anticancer agent (Noruzi, 2015). Seetharaman et al. (2017) have studied the fabrication of gold nanoparticles using an aqueous leaf extract of Crescentia cujete and the potency of its fruit was ignored. Berenuk (Crescentia cujete L.) fruit is widely used by the community in East Java as traditional medicine and have many active compound like saponins, flavonoids, cardenolides, tannins, and phenols (Hasanah et al. 2018; Ginting et al. 2018; Musa et al. 2019). In the present study, we have studied the synthesis of AuNPs using FFE 
from crescentia cujete and blue green alga to degrade the toxic chemicals may be produced during reduction process.

\section{Materials and Methods}

\section{Material and instrumentation}

The research specimen is fruits of Crescentia cujete Linn were collected from cilegon, Banten, Indonesia in june 2019. The chemicals used in this research were $\mathrm{HAuCl} 4.3 \mathrm{H} 2 \mathrm{O}(99,9 \%$, Sigma Aldrich and blue green alga ekstract. Instrument were used spectrometer uv-vis, FTIR, and TEM.

\section{Extraction and synthesis}

Dried green algae of $S$. platensis $(1 \mathrm{~g})$ powder was added to $10 \mathrm{~mL}$ of aquadest and The mixture was centrifuged at $5000 \mathrm{rpm}$ for $10 \mathrm{~min}$ (Suganya et al. 2014). The supernatant was used for synthesis of AuNPs. The fruits of Crescentia cujete Linn. were ssqueezed directly to get fresh fruit sample. Then the sample was filtered through What Mann Filter and the filtered extract were used for synthesis of AuNPs. The experimental synthesis method consisted in mixing $50 \mathrm{ml}$ of $\mathrm{HAuCl} 4.3 \mathrm{H} 2 \mathrm{O}$ (99,9\%, Sigma Aldrich) $5 \times 10^{-4} \mathrm{M}$ with $2 \mathrm{~mL}$ blue green alga ekstract and $2 \mathrm{~mL}$ fruit extract of crescentia cujete $\mathrm{L}$.

\section{Characterization of AuNPs}

The synthesized AuNPs was initially confirmed by UV-Vis spectroscopy at the wavelength of 200$650 \mathrm{~nm}$. FTIR analysis was carried out to identify the reduced bio-compound present in AuNPs. TEM samples of the gold nanoparticles synthesised using fruit and algae extract were prepared by placing drops of the product solution onto carbon-coated copper grids. TEM instrument operated at an accelerating voltage of $200 \mathrm{kV}$ (Seetharaman et al. 2017).

\section{Results}

The successful synthesis of gold nanoparticles can be proven using UV-VIS, FTIR, and TEM. Fig 12 shows $\mathrm{UV}-\mathrm{Vis}$ absorbance of $\mathrm{HAuCl}_{4}$ before and after reaction with fruit extract. The present of tanin as bioreductor compounds was confirmed by FTIR analysis (Fig 3-4). Fig 5 shows the size and morphology of AuNPs.

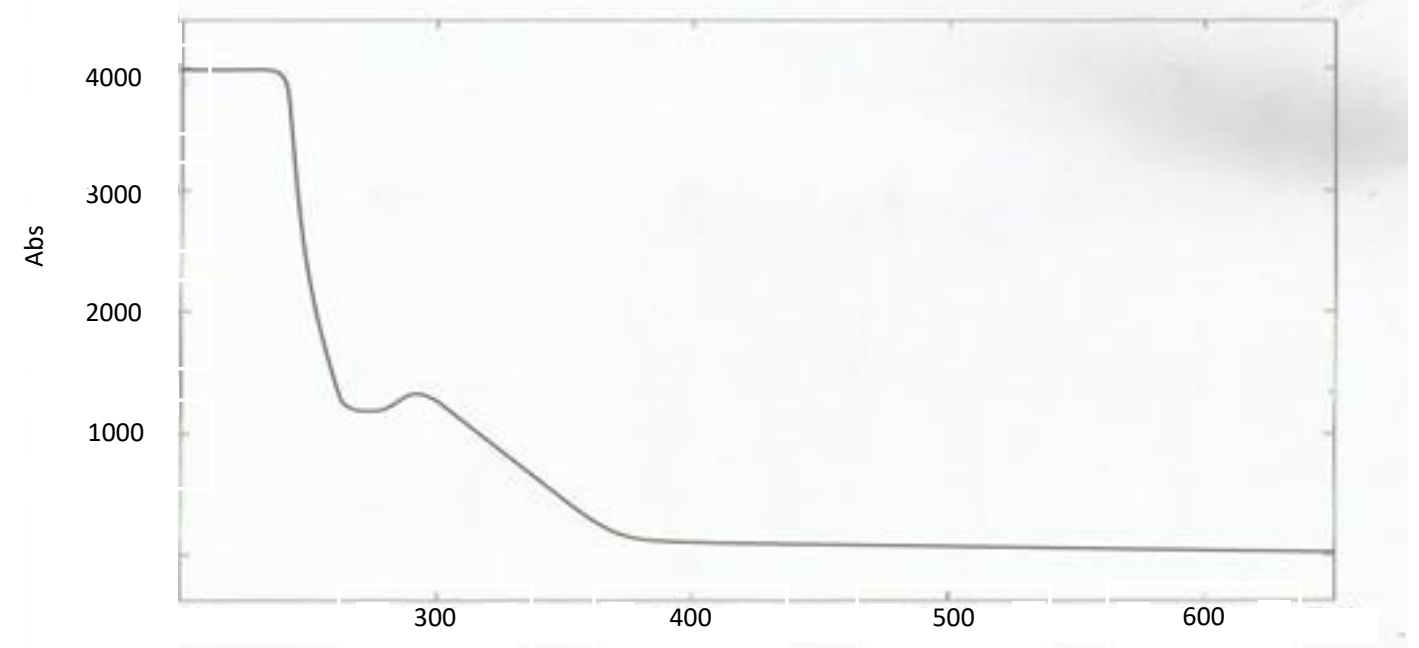

Fig 1. UV-Vis spectra of standard solution of $\mathrm{HAuCl}_{4}$ 
Synthesis and characterization of gold nanoparticles using fruit extract of crescentia cujete $L$

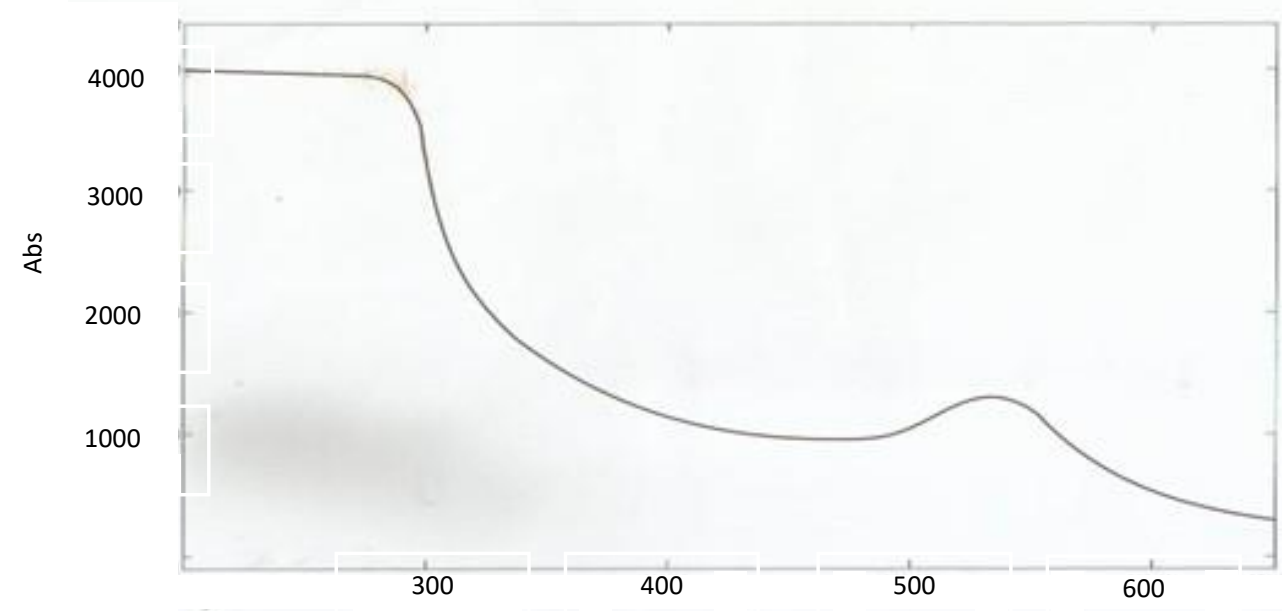

Fig 2. UV-Vis spectra of AuNPS using truit and algae extract

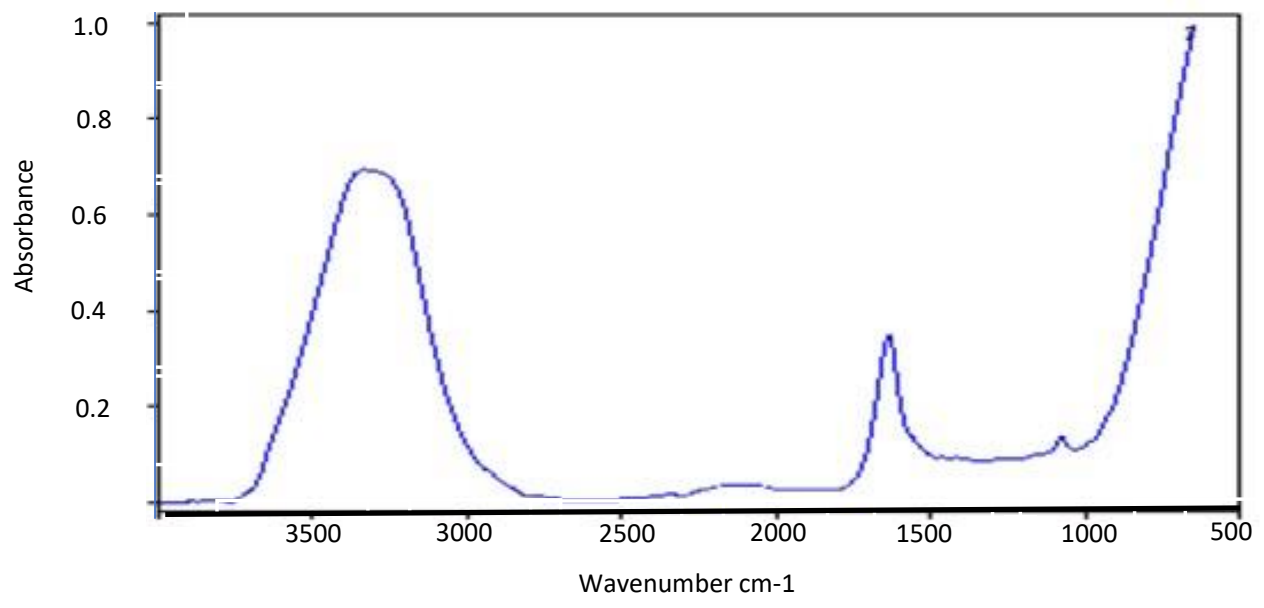

Fig 3. FTIR Absorbance of aqueous fruit extract

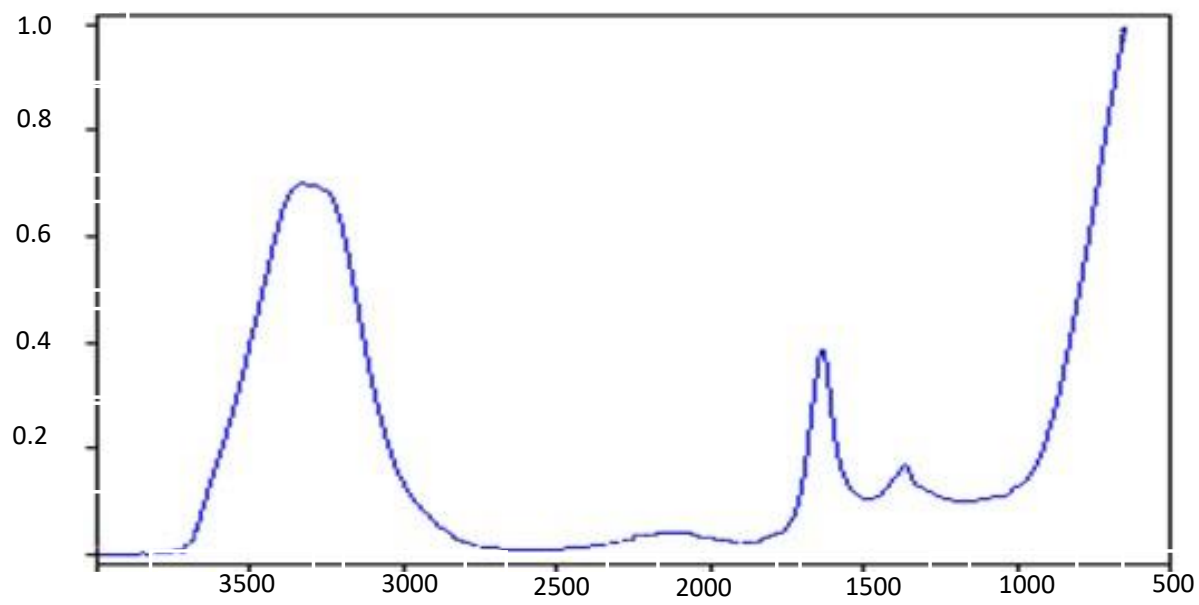

Fig 4. FTIR Absorbance of AuNPs 


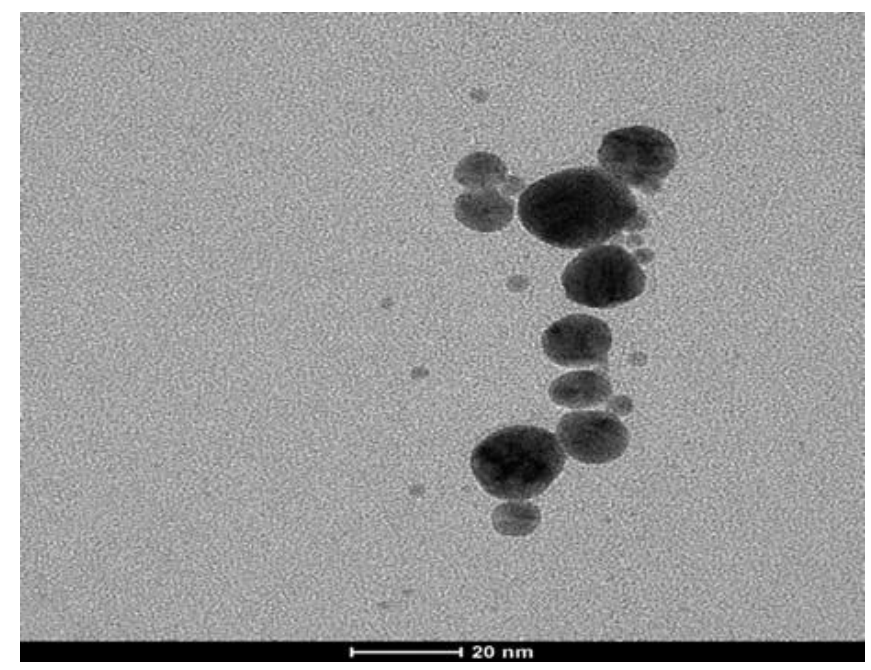

Fig 5. TEM images of AuNPs

\section{Discussion}

Figure 1 shows the absorbance spectrum in the visible region for standard solution of $\mathrm{HAuCl} 4$. Maximum absorption for this solution occurs at wavelength of approximately $300 \mathrm{~nm}$ which the caharacteristic of $\mathrm{HAuCl}_{4}$ before reaction with the fruit and algae extract (Setiawan et al. 2014).

The synthesized AuNPs was initially confirmed by visual colour change from yellow pale to ruby red due to excitation of Surface Plasmonic Vibrations. The formation of AuNPS was also measured using UV-Visible spectroscopy and usually ranges from $500-550 \mathrm{~nm}$ related to size, shape, dielectric constant, and collective oscillation of conduction electrons excited by the electromagnetic field of light (Rohiman et al. 2014). In our study, UV-Vis spectroscopic analysis of synthesized CCAuNPs produces intensely Bathochromic shift from $300 \mathrm{~nm}$ (Fig 1) to $531 \mathrm{~nm}$ (Fig 2). Fruit extract plays a role as reductor and stabilizer of AuNPs because of its ability to reduce Au3+ ions of chloroauric acid to AuO in which stabilized by other chemical compounds. Stability of AuNPs is important for application in pharmacological and biomedical studies. However, fruit extract contain secondary metabolites that are distasteful or toxic to consumers and can be easily degraded by alga extract (Menon et al. 2017).

Many bioactive compounds such as alkaloids, flavonoids, tannins, and saponins were present in fruits extract of crescentia cujete L (Billacura \& Laciapag, 2017). Tannins or phenolic compounds are effective reducing agent to to form high concentration of AuNPS by reduction of Au3+. The FTIR analysis revealed the present tanins in fruit extract (Fig 3). In the Fig. 3, two major vibrations stretches were observed at $1600-1750 \mathrm{~cm}-1$ corresponds to carbonyl $(\mathrm{C}=\mathrm{O})$ and $3300-3500 \mathrm{~cm}-1 \mathrm{O}-\mathrm{H}$ stretch or $\mathrm{H}$-bonded of alcohols and phenol groups. FTIR spectra also recorded for AuNPS which produces stronger peak for $1600-1750 \mathrm{~cm}-1$ due to phenolic oxidation (Fig 4). Unassigned peaks like $1300 \mathrm{~cm}-1$ may be attributed to the formation of new bonds between metallic nanoparticles AuNPs and the functional group present in the aqueous fruit extract. The presence of tannin was observed also using Ferric Chloride Test which form brown color to show positif result.

TEM results gave a clear indication on size and shape of AuNPs. Particle size is related to the surface are with the smaller size have shown higher acitivity. Fig 5 depicts the uniformity of the spherically shaped nanoparticles with average size of $10.11 \mathrm{~nm}$. Our research is in accordance with AuNPS using bioreductor extract of ketapang leaf with microwave irradiation (Rahmah, 2019). 


\section{Conclusion}

In this research, fruit extract of crescentia cujete $\mathrm{L}$ and algae are used for biosynthesise of gold nanoparticles an inexpensive, nature- friendly and simple process. The formation of AuNPS was proven by ultraviolet-visible spectroscopy, FTIR, and TEM which implies that AuNPS are in nano size and highly stable.

\section{Acknowledgments}

This work was supported by the ministry of research and higher education of the Indonesia Republic for funding this collaboration (RISTEKDIKTI) with scheme "Penelitian Dosen Pemula year 2019".

\section{References}

Billacura, M. P., \& Laciapag, G. C. R. (2017). Phytochemical screening, cytotoxicity, antioxidant, and anthelmintic property of various extract from Crescentia cujete Linn. fruit. Science International, 29(2), 31-35.

Ginting, S. N., Simanullang, E. K., Simanullang, L. P., Nainggolan, B., \& Silaban, S. (2018). The optimization of acid hydrolysis on bioethanol production from durian peel waste (Durio zibethinus murr). Jurnal Pendidikan Kimia, 10(2), 382-386, doi: 10.24114/jpkim.v10i2.10917.

Hasanah, U., \& Widhiastuti, H. T. (2018, November). Potency of Ethanol Extract from Berenuk (Crescentia cujete L.) Fruit Rind and Flesh as Antibacterial Agents. IOP Conf. Ser.: Earth Environ. Sci. 187012001 , doi: 10.1088/1755-1315/187/1/012001

Inayah, M., Maming., Zakir, M. (2014). Sintesis nanopartikel emas menggunakan bioreduktor dari ekstrak kulit buah manggis (Garcinia mangostana L.). Jurusan Kimia FMIPA Universitas Hasanuddin Makasar.

Menon, S., Rajeshkumar, S., \& Kumar, V. (2017). A review on biogenic synthesis of gold nanoparticles, characterization, and its applications. Resource-Efficient Technologies, 3(4), 516-527, doi: $10.1016 /$ j.reffit.2017.08.002

Musa, W. J., Bialangi, N., Situmeang, B., \& Silaban, S. (2019). Triterpenoid compound from metanol extract of mangrove leaves (Sonneratia alba) and anti-cholesterol activity test. Jurnal Pendidikan Kimia, 11(1), 18-23, doi: 10.24114/jpkim.v1li1.13124

Noruzi, M. (2015). Biosynthesis of gold nanoparticles using plant extracts. Bioprocess and Biosystems Engineering, 38(1), 1-14, doi: 10.1007/s00449-014-1251-0

Rahma, D. E. (2019). Sintesis nanopartikel emas menggunakan bioreduktor ekstrak daun ketapang (Terminalia catappa) dengan irradiasi microwave (Doctoral dissertation, Universitas Islam Negeri Maulana Malik Ibrahim).

Rohiman, A., Buchari., Amran, M.B., Endang, J., Irman, 1. (2014). Sintesis, karakterisasi, dan aplikasi gold nanoparticles (AuNPs) pada penumbuhan Silicon Nanowires (SiNWs). Research and Development on Nanotechnology in Indonesia, 1(2), 74-82.

Seetharaman, P., Chandrasekaran, R., Gnanasekar, S., Mani, 1., Sivaperumal, S. (2017). Biogenic gold nanoparticles synthesized using Crescentia cujete $\mathrm{L}$. and evaluation of their different biological activities. Biocatalysis and Agricultural Biotechnology, 11, 75-82, doi: 10.1016/j.bcab.2017.06.004

Setiawan, H., Anung, P., Hotmal, L., Rien, R., Mujinah., Dede, K., Witarti., Hambali., Abdul, M. (2014). Sintesis nanopartikel emas menggunakan reduktor trisodium sitrat. Prosiding Pertemuan Ilmiah Radioisotop, Radiofarmaka, Siklotron dan Kedokteran Nuklir, 95-101.

Suganya, K.S.U., Govindaraju, K., Kumar, V.G., Dhas, T.S., Karthick, V., Singaravelu, G., Elanchezhiyan, M. (2015). Blue green alga mediated synthesis of gold nanoparticles and its antibacterial efficacy against Gram positive organisms. Materials Science and Engineering, 47, 351-356, doi: 10.1016/j.msec.2014.11.043

Tripathi, R.M., Shrivastav, A., Shrivastav, B.R. (2015). Biogenic gold nanoparticles: As a potential candidate for brain tumor directed drug delivery. Artif Cells Nanomed Biotechnol, 43(5), 311-317, doi: 10.3109/21691401.2014.885445. 